\title{
Bacteriomorphs and associated minerals in the Las Cruces deposit, Spain.
}

\author{
J.JAVIER REY-SAMPER ${ }^{1}$, FERNANDO TORNOS ${ }^{2}$, CESAR $^{2}$ \\ MENOR-SALVAN ${ }^{3}$, IAN FRANCHI ${ }^{4}, \mathrm{XUCHAO} \mathrm{ZHAO}^{4}$ \\ AND MONIKE OGGERIN ${ }^{5}$ \\ ${ }^{1}$ Spanish National Research Council (CSIC) \\ ${ }^{2}$ Instituto de Geociencias (IGEO, CSIC-UCM) \\ ${ }^{3}$ Georgia Institute of Technology \\ ${ }^{4}$ Open University \\ ${ }_{5}^{5}$ Max Plank Institute for Marine Microbiology \\ Presenting Author: jrey@cab.inta-csic.es
}

Las Cruces is a volcanogenic massive sulphide deposit in the Iberian Pyritic Belt. It islocated below ca. $150 \mathrm{~m}$ of Tertiary marl and it hosts an uncommon zone of secondary alteration that makes it one of the richest copper deposits worldwide. The rocks capping the massive sulphides include a black sulfide and carbonate-rich rock with abundance of $\mathrm{Pb}, \mathrm{Ba}, \mathrm{Sn}, \mathrm{Bi}, \mathrm{As}, \mathrm{Hg}$, $\mathrm{Sb}, \mathrm{Ag}$ and $\mathrm{Au}$. Its origin is under study by our research group, and we hypothesize that-corresponds to an older gossan, formed when the massive sulphides were exposed sub-aerially, that has been deeply transformed by a rich anoxic microbial ecosystem while it was buried by a Tertiary marl sequence.

The Black Rock includes extremely well preserved and unique bacteriomorphs fossilized by sulfides. SEM and NanoSIMS studies show that sulphides in the rock occur with two different morphologies:

(a) Abundant, curved rod-shaped, of $0.5 \mu \mathrm{m}-1 \mu \mathrm{m}$ wide and 2 $\mu \mathrm{m}-8 \mu \mathrm{m}$ longcylindrical structures that likely correspond to bacteriomorphs. These structures preserve remnants of an external membrane replaced by sulfides (dominantly galena) and putative organules replaced by other sulphides, Fe-Ag sulfides, likely mackinawite or smythite. They coat oxides (hematite or goethite) or siderite-calcite as continuous mats, sometimes with several stacking layers. (b) Less abundant, also likely biogenic, structures include thin, long and curved -close to spirochaetes shape - of around $0.2 \mu \mathrm{m}$ wide and $1 \mu \mathrm{m}-3 \mu \mathrm{m}$ long. They have been located mostly inside fractures and cavities. They are also galena-rich on the surface and the internal structures are under study.

Both presumed organic structures quickly evolve to euhedral skeletal crystals, losing the original features. They coexist with later, euhedral crystals of tennantite, proustite, cinnabar, bornite, and cubanite as well as rounded grains of gold, also interpreted as of biogenic origin. 